\title{
It is not all about sodium: revealing tissue specificity and signalling roles of potassium in plant responses to salt stress
}

\author{
Honghong Wu • Xianchen Zhang • \\ Juan Pablo Giraldo • Sergey Shabala (iD
}

Received: 25 May 2018 / Accepted: 26 July 2018 / Published online: 14 August 2018

(C) Springer Nature Switzerland AG 2018

\begin{abstract}
Background Salinity is a global issue threatening agricultural production systems across the globe. While the major focus of plant salinity stress tolerance research has been on sodium, the transport and physiological roles of $\mathrm{K}+$ in plant salt stress response has received less attention. This review attempts to bridge this knowledge gap. Scope The major emphasis is on newly proposed $\mathrm{K}+$ signalling roles and plant salt tolerance cell- and tissuespecificity. In addition to summarizing the importance of $\mathrm{K}+$ retention for plant salt tolerance, we focus onaspects that were not the subject of previous reviews including (1) the importance of HAK/KUP family of transporters in $\mathrm{K}+$ uptake in salt stressed plants and its possible linkage with $\mathrm{Ca} 2+$ and ROS signalling; (2) control of xylem $\mathrm{K}+$ loading in salt stressed plants, control of phloem $\mathrm{K}+$ recirculation in salt stressed plants and the potential importance of plant's ability to efficiently coordinate $\mathrm{K}+$ signals between root and shoot; (3) the buffering capacity of the vacuolar $\mathrm{K}+$ pool; and
\end{abstract}

Honghong $\mathrm{Wu}$ and Xianchen Zhang contributed equally to this work.

Responsible Editor: Ismail Cakmak.

H. Wu $\cdot$ S. Shabala $(\bowtie)$

Tasmanian Institute of Agriculture, College of Science and Engineering, University of Tasmania, Hobart, TAS 7001,

Australia

e-mail: Sergey.Shabala@utas.edu.au

H. Wu $\cdot$ X. Zhang

State Key Laboratory of Tea Plant Biology and Utilization, Anhui Agricultural University, Hefei 230036 Anhui, China
(4) mechanisms of restoring the basal cytosolic $\mathrm{K}+$ levels by coordinated activity of tonoplast $\mathrm{K}+$-permeable channels.

Conclusions Overall, this review emphasises the need to fully understand the newly emerging roles of $\mathrm{K}+$ and regulation of its transport for improving salinity stress tolerance in plants.

Keywords Cell- and tissue- specificity $\cdot$ Potassium channels and transporters $\cdot$ Potassium homeostasis . Potassium retention $\cdot$ Programmed cell death $\cdot$ Signalling

\section{Introduction}

Soil salinity is a major environmental constrain to crop growth and yield affecting nearly $50 \%$ of all irrigated land in the world (Fita et al. 2015). To meet the projected demand of feeding 9.3 billion people at 2050, global agricultural production must be increased by $60 \%$ from

H. Wu $(\bowtie) \cdot$ J. P. Giraldo

Department of Botany and Plant Sciences, University of

California, Riverside, California 92521, USA

e-mail: honghong.wu@ucr.edu

S. Shabala

Department of Horticulture, Foshan University, Foshan 528000 Guangdong, China 
its 2005-2007 levels (van Ittersum et al. 2016). Therefore, understanding the mechanisms underlying plant salt tolerance, especially its ion transport-related traits, would improve breeding robust salt tolerant crop species and thus provide a feasible way to mitigate the possible food shortage in the future.

Traditionally, adverse effects of soil salinity have been associated with $\mathrm{Na}^{+}$toxicity, prompting a significant number of studies on this topic (Munns and Tester 2008; Horie et al. 2012; Deinlein et al. 2014; Maathuis 2014; Hanin et al. 2016). However, an increase in $\mathrm{Na}^{+}$content is always accompanied by $\mathrm{K}^{+}$loss in plants exposed to salt $(\mathrm{NaCl})$ stress. $\mathrm{K}^{+}$is an essential macronutrient in plants comprising generally 4 to $6 \%$ of its dry matter and is recognized as a rate-limiting factor for crop yield and quality (Dreyer and Uozumi 2011; Zorb et al. 2014). $\mathrm{K}^{+}$plays an important role in plant response to both biotic (disease and pests) and abiotic stresses such as drought, salinity, cold, and waterlogging (Wang et al. 2013b; Shabala and Pottosin 2014). Potassium also has a key role in protein synthesis (Fischer 1968), charge balancing, and phloem sugar loading (Gajdanowicz et al. 2011; De Schepper et al. 2013). $\mathrm{K}^{+}$ deficiency leads to reduced photosynthesis, and the replacement of $\mathrm{K}^{+}$by organic osmolytes for the purpose of osmotic adjustment could result in reduced growth (Tsay et al. 2011). A new signalling role of $\mathrm{K}^{+}$has recently started to emerge (Anschütz et al. 2014; Rubio et al. 2014). The latter topic is a major focus of this review.

\section{$\mathrm{K}^{+}$retention in the cytosol: An overlooked mechanism in plant salt tolerance}

Salinity stress induces chronic $\mathrm{K}^{+}$deficiency in plants while the capacity of plants to counteract salinity stress strongly depends on $\mathrm{K}^{+}$availability (Maathuis and Amtmann 1999). Under salinity stress, $\mathrm{NaCl}$-induced $\mathrm{K}^{+}$ loss from plants is a common phenomenon, and this event is more pronounced in salt sensitive than tolerant plant varieties (Chen et al. 2007). GORK (guard cell outward rectifying $\mathrm{K}^{+}$channel) and ROS-activated NSCC (nonselective cation channels) channels are known to mediate $\mathrm{NaCl}$-induced $\mathrm{K}^{+}$efflux from the cytosol to the apoplast (Jayakannan et al. 2013; Wu et al. 2015b). With the onset of salt stress, the plasma membrane potential is rapidly depolarized activating voltage gated GORK channels and resulting in $\mathrm{K}^{+}$efflux. Accumulation of ROS under stress conditions could further activate both GORK and ROSactivated NSCC channels inducing more $\mathrm{K}^{+}$efflux. This leads to a rapid loss of $\mathrm{K}^{+}$from the cytosol which in turn disrupts the homeostasis of cytosolic $\mathrm{Na}^{+} / \mathrm{K}^{+}$ratio, a hallmark of plant overall salt tolerance (Dasgan et al. 2002; Hauser and Horie 2010). In recent years, the ability of various plant tissues to retain $\mathrm{K}^{+}$under salt stress (termed cytosolic $\mathrm{K}^{+}$retention) has been shown to be an important trait for plant salt tolerance (Table 1). In wheat, $\mathrm{K}^{+}$efflux measured from root mature zone after salt application was found to be strongly and negatively correlated with plant yield at the harvest (Cuin et al. 2008). Salt tolerant barley varieties showed 3-fold higher ability to retain $\mathrm{K}^{+}$in the roots than the sensitive genotypes (Chen et al. 2007). Smethurst et al. (2008) found that the tolerant lucerne varieties had better root $\mathrm{K}^{+}$retention ability than the sensitive counterparts. In barley and wheat, $\mathrm{NaCl}$-induced $\mathrm{K}^{+}$ efflux in leaf mesophyll was significantly higher in salt sensitive varieties than salt tolerant varieties ( $\mathrm{Wu}$ et al. 2013, 2015c). Also, salt tolerant bread wheat varieties exhibit significantly higher mesophyll $\mathrm{K}^{+}$retention ability than the relative sensitive durum wheat varieties (Wu et al. 2014). Similar results were also reported for Arabidopsis (Wu et al. 2018b), poplar (Sun et al. 2009), cotton (Wang et al. 2016a), and brassica (Chakraborty et al. 2016b). Thus, $\mathrm{K}^{+}$retention ability in root and leaf tissues appears to be an important and previous largely overlooked trait concomitant to salt tolerance in plants.

However, similar to $\mathrm{Na}^{+}$data (Genc et al. 2007), there are some noticeable exceptions from the rule. While the extent of $\mathrm{NaCl}$-induced $\mathrm{K}^{+}$efflux from the root correlated with salinity stress tolerance in both wheat (Cuin et al. 2009) and barley (Chen et al. 2007), the magnitude of $\mathrm{K}^{+}$efflux even in most tolerant barley variety exceeds the flux value in any of tested wheat varieties, under similar experimental conditions. This comes at a stark contrast with the fact that barley species possess much higher salt tolerance compare with either durum or bread wheat (Munns and Tester 2008). What may be the reason for this discrepancy?

To further investigate this point, we have analysed the literature data, tabulating reported numbers for the relative value ( $\%$ control) in root and shoot $\mathrm{K}^{+}$content for seven major crop species - wheat, rice, barley, maize, Vicia faba, tomato, and cotton - and then plotting these changes against reported salinity tolerance thresholds. The latter was defined as an electrical conductivity of the soil solution at which plant growth starts to decline (see Hedrich and Shabala 2018 for details). As shown in Fig. 1a, a strong and positive correlation was 
Table 1 Reported association between $\mathrm{K}^{+}$retention trait and salt tolerance in various plant species

\begin{tabular}{llll}
\hline Species & Tissues & Methods/approaches & Reference \\
\hline Wheat & Root, leaf & $\mathrm{K}^{+}$fluxes, $\mathrm{K}^{+}$content & Cuin et al. 2008, Wu et al. 2014 \\
Barley & Root, leaf & $\mathrm{K}^{+}$fluxes, $\mathrm{K}^{+}$content & Chen et al. 2005, Wu et al. 2015c \\
Maize & Root & $\mathrm{K}^{+}$content & Gao et al. 2016 \\
Cotton & Root & $\mathrm{K}^{+}$fluxes, $\mathrm{K}^{+}$content & Wang et al. 2016a \\
Rice & Root, shoot & $\mathrm{X}_{\text {-ray, } \mathrm{K}^{+} \text {content }}$ & Xu et al. 2011 \\
Lucerne & Root, & $\mathrm{K}^{+}$fluxes & Smethurst et al. 2008 \\
Poplar & Root & $\mathrm{K}^{+}$fluxes & Sun et al. 2009 \\
Soybean & Leaf & $\mathrm{K}^{+}$content & Essa 2002, Lu et al. 2016 \\
Brassica & Root & $\mathrm{K}^{+}$fluxes & Chakraborty et al. 2016b \\
Arabidopsis & Root, leaf & $\mathrm{K}^{+}$fluxes & Bose et al. 2013, Wu et al. 2018b \\
\hline
\end{tabular}

observed ( $r=0.882, P=0.009)$ between amount of $\mathrm{K}^{+}$ retained in shoot or leaf under salinity and overall plant performance (salinity threshold measured as an electrical conductivity of the soil solution at which plant growth starts to decline), suggesting the importance of this trait for overall salt stress tolerance. In plant roots, however, this correlation was negative (Fig. 1b). In fact, previous studies report that salt-sensitive species may even increase the overall root $\mathrm{K}^{+}$content compared with non-saline controls (Ai-Rawahy et al. 1992; Hamada 1994; Bulut and Akınc1 2010). This may be indicative that salt-tolerant species possess a better ability to control long-distance $\mathrm{K}^{+}$transport, either by its more efficient xylem loading and delivery to the shoot, or minimising the extent of $\mathrm{K}^{+}$recirculation in the phloem. Both these scenarios are discussed in more detail in the following sections.

Supporting the above notion, recent studies showed that mutualistic fungi can enhance plant salt stress tolerance through upregulation of genes related to $\mathrm{K}^{+}$ transport and thus maintain better $\mathrm{K}^{+} / \mathrm{Na}^{+}$homeostasis. For example, arbuscular mycorrhizal fungi inoculation upregulate the expression of RbSOS1, RbHKT1, and $R b N H X 1$, and significantly improve $\mathrm{K}^{+}$content and reduced $\mathrm{Na}^{+}$content in root and leaf of black locust under $200 \mathrm{mM} \mathrm{NaCl}$ (Chen et al. 2017). Similar results were also showed in other plant species inoculated with mutualistic fungi, e.g. Arabidopsis inoculated with Piriformospora indica (Abdelaziz et al. 2017) and bermudagrass inoculated with Aspergillus aculeatus (Xie et al. 2017). Interestingly, while AtHKT1 (gene encoding a $\mathrm{Na}^{+}$selective transporter) is downregulated in salt stressed Arabidopsis, TsHKT1;2 encoding a $\mathrm{K}^{+}$ selective transporter is upregulated in salt stressed halophytic Arabidopsis relative, Thellungiella salsuginea (Ali et al. 2012, 2013). These findings further emphasise the importance of maintaining $\mathrm{K}^{+}$homeostasis for plant salt tolerance.

Furthermore, accumulation of compatible solutes e.g. water soluble carbohydrates and amino acids in stem tissue and subsequent remobilization of these compatible solutes to developing grains under salinity stress can decrease plants' dependency on photosynthesis and thus can reduce its yield loss from salt stress (Kerepesi and Galiba 2000; Yang and Zhang 2006; Sharbatkhari et al. 2016). At the same time, potassium availability was critical for accumulation of water-soluble carbohydrates (Krumm et al. 1990) and, specifically, fructans (Livingston et al. 2009). Fructan can account for up to $85 \%$ water soluble carbohydrates in wheat stem internodes (Yanez et al. 2017), and a positive correlation between fructan accumulation and higher efficiency of its remobilization and salinity tolerance was reported in wheat (Sharbatkhari et al. 2016). Furthermore, some fructan related enzymes e.g. fructokinase in chloroplast, are activated by $\mathrm{K}^{+}$(Table 2 ).

\section{$\mathrm{K}^{+}$in plant salt stress responses: Emerging new roles}

Cytosolic $\mathrm{K}^{+}$efflux as a "metabolic switch"

In addition to being an essential macronutrient, $\mathrm{K}^{+}$is also a major determinant of the cell's fate (Shabala 2009, 2017; Anschütz et al. 2014). This dual role of $\mathrm{K}^{+}$(nutritional and signalling) is poorly understood. As 
Fig. 1 Correlation between plant salinity tolerance threshold (measured as the electrical conductivity of the soil solution in which plant growth starts to decline) and the relative amount of $\mathrm{K}^{+}$retained in shoots (a) or roots $(\mathbf{b})$ in plants grown under saline conditions $(\sim 100 \mathrm{mM}$ $\mathrm{NaCl})$. c Relative change in retained root $\mathrm{K}^{+}$vs changes in the shoot $\mathrm{K}^{+}$content. Seven common crops (wheat, barley, rice, maize, tomato, Vicia faba and cotton) are represented
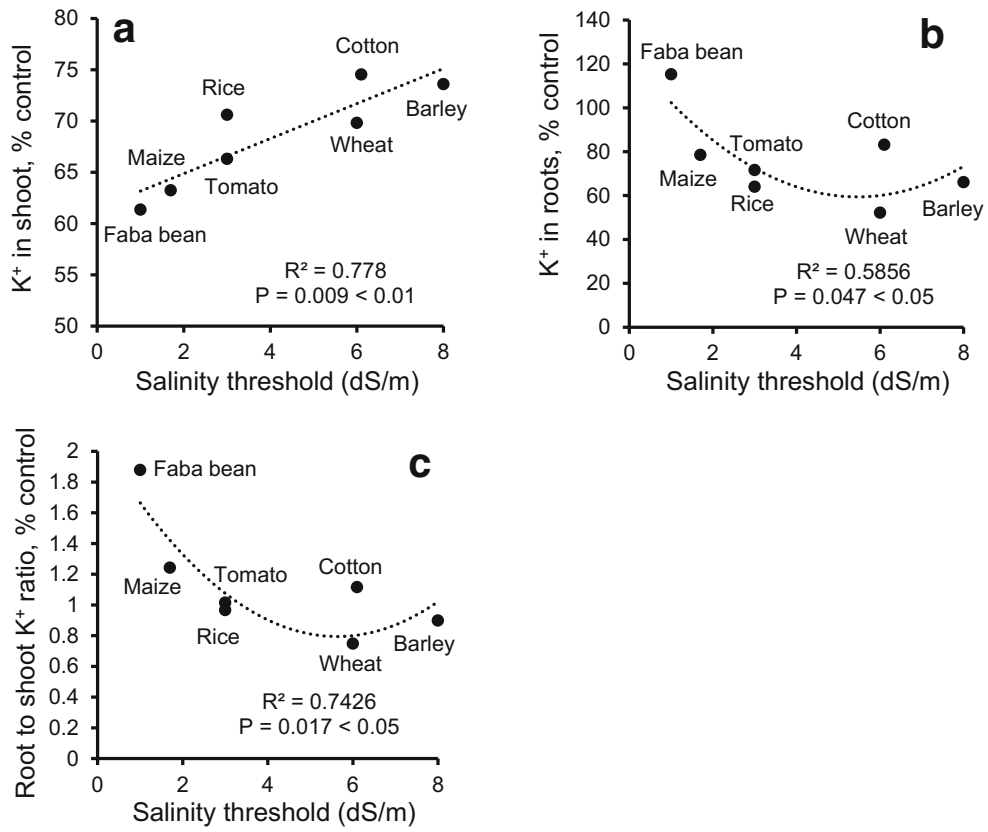

mentioned above, salinity stress induced $\mathrm{K}^{+}$loss is a common phenomenon in plants. $\mathrm{K}^{+}$efflux is correlated with electrolyte leakage (up to 80\%) (Pavlovkin et al. 1986), a hallmark of stress response in intact plant cells. Cytosolic $\mathrm{K}^{+}$efflux has been proposed to play the role of "metabolic switch" by providing inhibition of energy-consuming biosynthesis that releases energetic molecules for defence and reparation needs (Demidchik et al. 2014). This "metabolic switch" role of cytosolic $\mathrm{K}^{+}$efflux could be important for salt stressed plants to halt growing and use the available energy to finish a full life cycle.

To further understand the possible role of the cytosolic $\mathrm{K}^{+}$efflux as metabolic switch, we looked at the $\mathrm{K}^{+}$ activated enzymes related to the energy-consuming processes in plant cells. The likely candidates are listed in Table 2. Further studies are needed to understand their activation thresholds, tissue-specific changes in their activity, and associated changes in cytosolic and organelle-specific $\mathrm{K}^{+}$concentrations in various species.

Rapid and severe cytosolic $\mathrm{K}^{+}$efflux induced programmed cell death

Programmed cell death (PCD) is a common phenomenon in salt stressed plants (Huh et al. 2002; Li et al. 2007; Pan et al. 2016). PCD represents one of the forms of apoptosis (Suzanne and Steller 2013) and facilitates the removal of redundant, misplaced, or damaged cells. While the physiological role of PCD under saline conditions is still a matter of debate (Huh et al. 2002; Shabala 2009), the causal relationship between $\mathrm{K}^{+}$efflux and stress induced PCD is beyond any doubt. Overexpressing antiapoptotic CED-9 gene in tobacco mesophyll has reduced salt-stress induced $\mathrm{K}^{+}$leak from this tissue two-fold and resulted in a salt-tolerant phenotype (Shabala et al. 2007b). Arabidopsis plants lacking functional GORK channels showed much slower development of the PCD symptoms when treated with $\mathrm{NaCl}$ or hydroxyl radicals (Demidchik et al. 2010). gork-2 mutant also exhibits increased uptake of $\mathrm{Rb}^{+}$ than Col-0 (Osakabe et al. 2013). The blockage of $\mathrm{K}^{+}$ efflux channels by TEA reduces the extent of PCD in wild-type Arabidopsis roots, suggesting a causal relationship between cytosolic $\mathrm{K}^{+}$efflux and PCD development.

$\mathrm{K}^{+}$efflux-mediated PCD events are intrinsically related to the ROS generation in stress-affected cells. A decrease in the cytosolic $\mathrm{K}^{+}$may stimulate ROS generation though NADPH oxidase (Shin and Schachtman 2004) and peroxidase (Kim et al. 2010) mediated pathways. For example, mutation of an NADPH oxidase gene (rhd2) prevents the upregulation of HAK5 gene that is highly induced by $\mathrm{K}^{+}$deficiency, whereas its expression in the NADPH oxidase Arabidopsis mutant is restored by application of extracellular $\mathrm{H}_{2} \mathrm{O}_{2}$ (Shin 


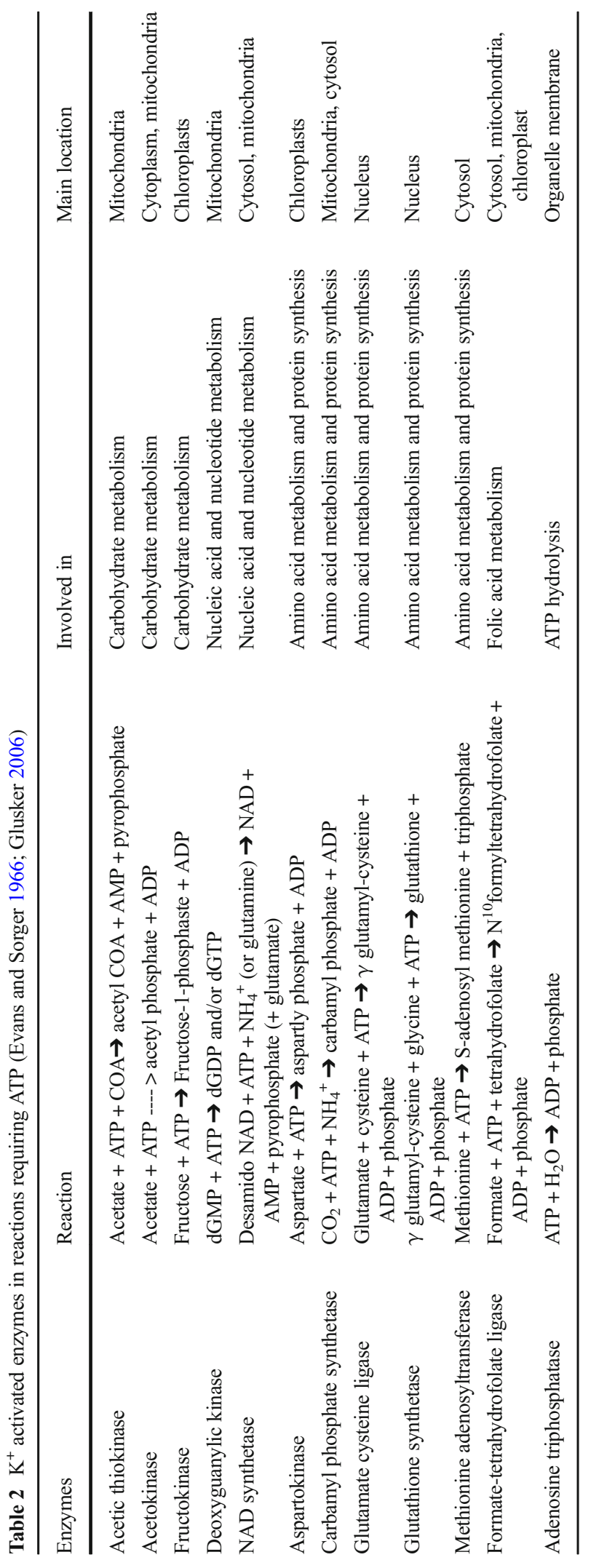




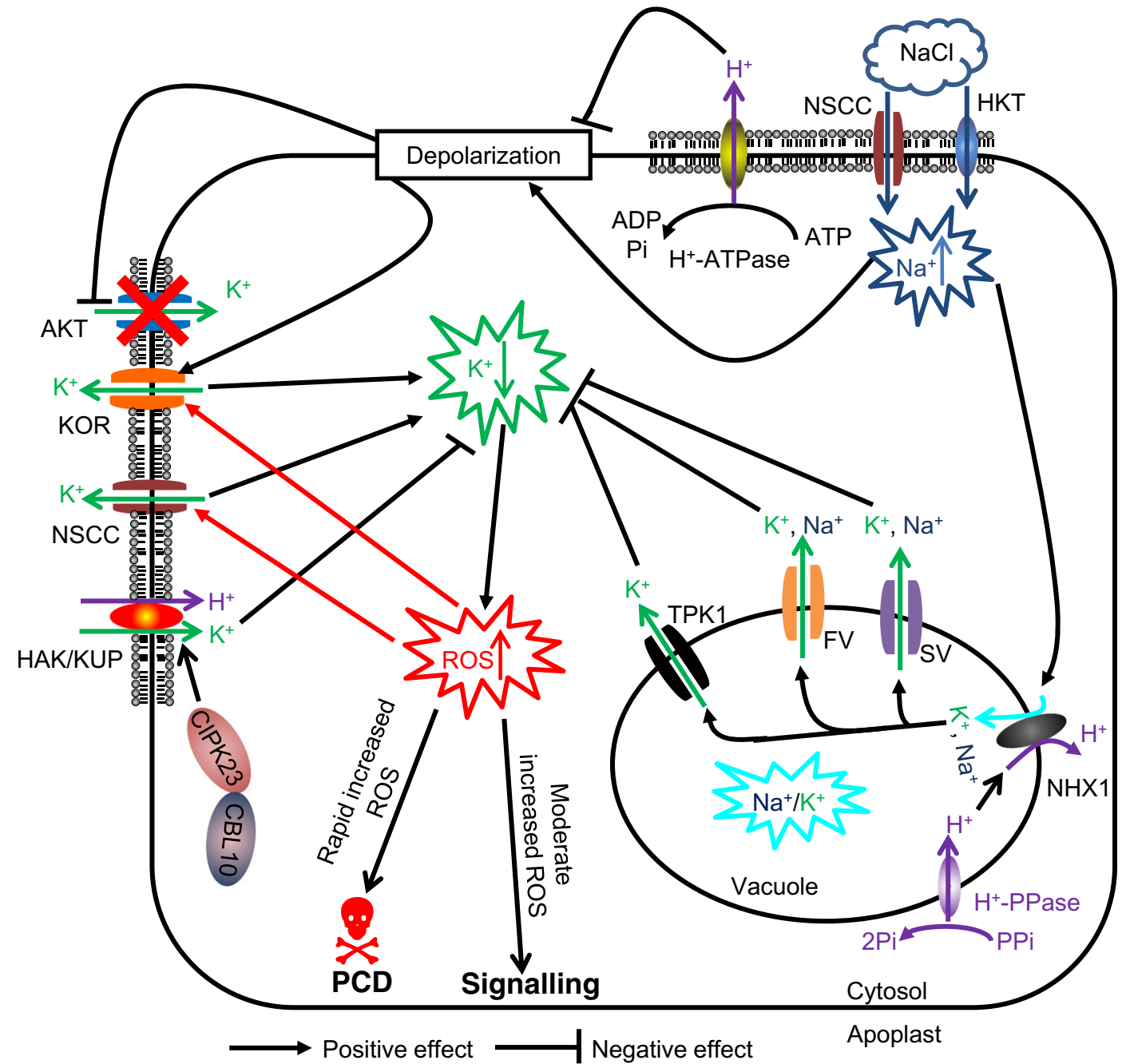

Fig. 2 A schematic diagram depicting membrane transporters mediating $\mathrm{NaCl}$-induced $\mathrm{K}^{+}$efflux from the cytosol and its relationship with ROS signaling. $\mathrm{K}^{+}$transport across the tonoplast membrane is also shown as a mechanism buffering cytosolic $\mathrm{K}^{+}$depletion

and Schachtman 2004). Also, AtrbohD and AtrbohF mutants have reduced $\mathrm{K}^{+}$content compared with WT Arabidopsis under salt stress. The $\mathrm{NaCl}$ induced decrease of $\mathrm{K}^{+}$content could be alleviated by application of exogenous $\mathrm{H}_{2} \mathrm{O}_{2}$ (Ma et al. 2012). In recent years, the concept of a dual role of ROS in plant biology has been developed and accepted (Miller et al. 2010; Petrov et al. 2015; Mittler 2017). According to this concept, low concentrations of ROS play an important signalling role in plant adaptive and developmental responses, while at high concentrations ROS are detrimental to the integrity of key cell structures and may trigger PCD. Thus, a moderate $\mathrm{K}^{+}$decrease could generate a low level of accumulated ROS essential for signalling. This high level of accumulated ROS could in turn activate $\mathrm{K}^{+}$ efflux channels, thus resulting in more $\mathrm{K}^{+}$loss. A more rapid and severe $\mathrm{K}^{+}$loss can lead to a high level ROS accumulation resulting acute ROS toxicity and thus PCD in plant cells (Fig. 2). It has also been proposed that superoxide anion could post-transcriptionally regulate GORK channel and allow sustained $\mathrm{K}^{+}$effluxes during PCD (Tran et al. 2013). The magnitude and timing of cytosolic $\mathrm{K}^{+}$changes might be related to these different outcomes. The cytosolic $\mathrm{K}^{+}$spikes likely operate as messengers that signal and shape plant adaptive stress responses including those to salinity (Shabala 2017).

Besides the above mentioned $\mathrm{K}^{+}$signalling role, $\mathrm{K}^{+}$ uptake is also known to be required for proper cell-cycle progression during the transition from $\mathrm{G} 1$ to $\mathrm{S}$ phase 
(Sano et al. 2007), and a threshold level of $\mathrm{K}^{+}$is needed for re-enter the cell cycle (Sano et al. 2007, 2009). It has been shown that at G1 phase, a Shaker-type NKT1 inward rectifying $\mathrm{K}^{+}$channel was transcriptionally induced in tobacco BY-2 cells, whereas $\mathrm{K}^{+}$outward rectifying channel (NTORK1) transcripts dominated the $\mathrm{S}$ phase (Sano et al. 2009). Together, these results suggest a role of $\mathrm{K}^{+}$channels in regulating cell division and cellcycle progression.

\section{Cell- and tissue- specificity of functional expression of channels and transporters mediating salt-induced $\mathbf{K}^{+}$efflux}

Plant salt tolerance is achieved by the combination of different salt tolerance mechanisms and sub-traits. The coordination of these mechanisms and sub-traits likely vary widely between plant species. Cell- and tissuespecificity in plant responses to salinity is reported in several plant species including Arabidopsis (Dinneny et al. 2008), wheat (Wu et al. 2015a, 2018a), and barley (Shabala et al. 2016). For example, Shabala et al. (2006) showed that higher salt sensitivity in the barley root apex compared to mature zone is linked to its higher potency for $\mathrm{NaCl}$-induced $\mathrm{K}^{+}$efflux. More details of channel and transporter activities at tissue- specific level still need to be revealed.

$\mathrm{K}^{+}$content in the cell represents a balance between $\mathrm{K}^{+}$efflux and $\mathrm{K}^{+}$uptake. These two processes are mediated by a number of $\mathrm{K}^{+}$channels and transporters that are being reported to have cell- and tissue- specificity. NaCl-induced $\mathrm{K}^{+}$efflux in barley leaf mesophyll (Wu et al. 2013) and root mature zone (Chen et al. 2007) is mainly mediated by the depolarization activated KOR/GORK channel. However, membrane potential control might not be essential for maintaining $\mathrm{K}^{+}$homeostasis in the root elongation zone, where $\mathrm{K}^{+}$efflux is mediated mainly by voltage independent NSCC channels, compared with the root mature zone cells where depolarization activated KOR channels play a major role (Wu 2016). Other examples include polyaminesensitive NSCC channel and ROS-activated NSCC channels in pea mesophyll cells (Shabala et al. 2007a) and root mature zone cells (Bose et al. 2014), and NSCC channels and KOR channels in either wheat mesophyll (Chakraborty et al. 2016a) or root mature zone (Cuin et al. 2012) cells, respectively. Compared with high expression of McHAK4 in all tissues, McHAK2 and
McHAK3 are predominantly present in stems and root tissues in common ice plants (Mesembryanthemum crystallinum) respectively ( $\mathrm{Su}$ et al. 2002). AKT1 and AKT2 contribute equally to the $\mathrm{K}^{+}$permeability in Arabidopsis mesophyll cells whereas AKT1 contributes predominantly to the $\mathrm{K}^{+}$permeability of the plasma membrane in the apical root cells (Dennison et al. 2001). OsAKT1 overexpression line shows increased $\mathrm{K}^{+}$tissue level (Ahmad et al. 2016b) whereas Atakt1 knockout line exhibits a similar $\mathrm{K}^{+}$efflux as Clo-0 under salt stress (Shabala et al. 2006). Furthermore, salt tolerant rice variety has higher relative expression of root OsAKT1 than the sensitive one under salt stress (Kavitha et al. 2012). Also, in common ice plants, Arabidopsis $A K T$ homologs Mkt1 is root specific, but Mkt 2 is found in leaves and flowers ( $\mathrm{Su}$ et al. 2001). Together, these results indicate that $\mathrm{K}^{+}$retention in plant salt tolerance is regulated in a strict cell- and tissue- specific manner. More attention should be paid to this fact in order to better engineering/breeding crops with stronger $\mathrm{K}^{+}$retention ability.

Another important aspect that needs to receive a full attention in the future studies is causal relationship between $\mathrm{NaCl}$-induced $\mathrm{K}^{+}$efflux and changes in the cell metabolic profile. Using barley as an example, Shabala et al. (2016) demonstrated that $\mathrm{NaCl}$-induced $\mathrm{K}^{+}$efflux from the root apex was about 10-folds higher than that from the mature root zone. At the same time, out of 75 analyzed metabolites, 30 were significantly changed in the root apex. This included 10 out of 25 tested amino acids and seven of 16 organic acids. No such changes, however, were observed in the mature root zone (Shabala et al. 2016). Many of them were shown to modulate ROS sensitivity of $\mathrm{K}^{+}$transporters in roots (Cuin and Shabala 2007), or directly gate $\mathrm{K}^{+}$ channels. For example, salt tress causes a significant (56 fold) increase in glutamate (Glu) and glycine (Gly) levels in the barley root apex (Shabala et al. 2016). Plant glutamate receptor-like (GLR) genes are closely related to mammalian ionotropic Glu receptors (Price et al. 2012), which operate as Glu- and Gly-gated NSCCs that catalyze the uptake of $\mathrm{K}^{+}, \mathrm{Na}^{+}$, and $\mathrm{Ca}^{2+}$ into neurons (Sohn 2013). It has been proposed that glycine plays a role in the gating of plant glutamate receptors (GLRs) (Dubos et al. 2003). Twenty of 40 NSCC in plants are classified as GLRs (Demidchik and Maathuis 2007; Price et al. 2012; Forde 2014). Thus, the preferential tissue-specific stress-induced increase in the Glu/ Gly levels in the root apex may operate upstream of 
$\mathrm{Ca}^{2+}$-NADPH oxidase "hub" (Demidchik 2018), shaping cytosolic free $\mathrm{Ca}^{2+}$ and ROS "signatures" and affecting intracellular ionic homeostasis. This $\mathrm{Ca}^{2+}$ NADPH oxidase "hub" concept implies that stressinduced elevation in the cytosolic free $\mathrm{Ca}^{2+}$ induces an increase in the NADPH oxidase-mediated production of ROS in the apoplast. Vice versa, extracellular ROS activate $\mathrm{Ca}^{2+}$ influx through $\mathrm{Ca}^{2+}$-permeable ion channels, thus forming a self-amplifying mechanism. Another illustration of the causal link between salt stress-induced changes in plant metabolic and ionic profile comes from experiments on halophytes (KianiPouya et al. 2017), showing tissue-specific changes in GABA (3 fold decrease), inositol (1.24 fold decrease) and sucrose (3.19 fold increase) content, and their impact on $\mathrm{NaCl}$ sequestration in epidermal bladder cells in Chenopodium quinoa.

\section{$\mathrm{K}^{+}$transport in plants under salt stress}

Control of $\mathrm{K}^{+}$uptake in salt stressed plants

$\mathrm{K}^{+}$uptake from soil to plants is mediated by channels and transporters (Very et al. 2014; Nieves-Cordones et al. 2016). The typical $\mathrm{K}^{+}$concentration in a soil solution ranges between 0.1 and $1 \mathrm{mM}$ (Wang and $\mathrm{Wu}$ 2013) whereas cell cytosolic $\mathrm{K}^{+}$concentration is about $100 \mathrm{mM}$. Thus, an efficient $\mathrm{K}^{+}$uptake system in plants is required to uptake $\mathrm{K}^{+}$from soil, especially under salinity stress condition. The high affinity of $\mathrm{K}^{+}$uptake mediated mainly by KT/HAK/KUP family and low affinity of $\mathrm{K}^{+}$uptake via channel-based mechanism influence/control $\mathrm{K}^{+}$transport in plants at low and high external $\mathrm{K}^{+}$concentration, respectively (NievesCordones et al. 2010, 2014; Very et al. 2014). The Shaker-type AKT family play the main role in a passive potassium uptake. AKT1 inward rectifying $\mathrm{K}^{+}$channel is shown to be predominantly in roots (Dennison et al. 2001; Ahmad et al. 2016b), whereas AKT2 and AKT1 contributed equally in mesophyll cells (Dennison et al. 2001). AKT2 has two different gating modes and its voltage threshold for activation can be either within the physiological range (gating mode 1), or shifted towards considerably more positive voltages (gating mode 2 ). Gating mode 1 AKT2 channels behave as delayed $\mathrm{K}^{+}$selective inward rectifiers while gating mode 2 AKT2 channels are $\mathrm{K}^{+}$-selective 'open leaks' in the physiological range of membrane potential (Michard et al. 2005).
However, the plant plasma membrane potential is significantly depolarized under salt stress, so AKT family mediated $\mathrm{K}^{+}$uptake is thermodynamically not possible, at least at the early salt stress stage. Thus, HAK/KUP $\mathrm{K}^{+}$ transporter family plays the main role for $\mathrm{K}^{+}$uptake in plants' response to salt stress. For example, the stimulation of the relative expression of McHAK1, McHAK2, McHAK3 and McHAK4 genes has been shown in ice plant exposed to high salinity $(400 \mathrm{mM} \mathrm{NaCl})(\mathrm{Su}$ et al. 2002). Relative expression level of $M e K U P 2, M e K U P 3$, MeKUP4, MeKUP6, MeKUP8, and MeKUP17 genes is upregulated in salt stressed cassava plant $(\mathrm{Ou}$ et al. 2018). OsHAK 21 functions in the maintenance of $\mathrm{K}^{+}$ homeostasis and thus salt tolerance in rice plant (Shen et al. 2015). AtHAK5 and KUP7 functions in $\mathrm{K}^{+}$ deprivation- induced high-affinity $\mathrm{K}^{+}$uptake in Arabidopsis roots (Gierth et al. 2005; NievesCordones et al. 2010; Han et al. 2016). Overexpression of OsHAK5 significantly improved shoot $\mathrm{K}^{+}$accumulation and biomass in overexpression lines under salt stress compared with the WT rice (Yang et al. 2014). Mutation of OsHAK1-D resulted in significantly reduced root and shoot $\mathrm{K}^{+}$content and biomass in the rice mutant line (Chen et al. 2015). It should be noted that $\mathrm{HAK} / \mathrm{KUP}$ transporters are usually regarded as $\mathrm{K}^{+} / \mathrm{H}^{+}$ symporters (Rodríguez-Navarro 2000; Grabov 2007), which requires ATP for $\mathrm{H}^{+}$-ATPase pumping of $\mathrm{H}^{+}$to maintain the $\mathrm{H}^{+}$gradient across a membrane. Thus, the availability of ATP and its allocation to plasma membrane might be another factor affecting $\mathrm{K}^{+}$uptake in salt stressed plants. Also, expression of these transporters often decrease under saline conditions (e.g. AtHAK5 expression in Arabidopsis; Nieves-Cordones et al. 2010). However, even under this reduced gene expression conditions these transporters are the only systems involved in high-affinity $\mathrm{K}^{+}$uptake under salinity.

Besides the possibility of the specificity of HAK/ $\mathrm{KUP} \mathrm{K}^{+}$transporters at cell- and tissue- level in controlling $\mathrm{K}^{+}$uptake in plants' response to salt stress, its relationship with other signalling events e.g. $\mathrm{Ca}^{2+}$ signature and ROS signalling in salt stressed plants should be also considered in future studies. After onset of salt stress, plant has two cytosolic $\mathrm{Ca}^{2+}$ peaks (Schmöckel et al. 2015; Shabala et al. 2015). These cytosolic $\mathrm{Ca}^{2+}$ elevation can in turn activate calcineurin B-like (CBL) calcium sensors e.g. CBL4 and CBL10, and thus CIPKs. CBL10-CIPK23 complex activates HAK5 in vivo (Ragel et al. 2015), suggesting that HAK/KUP activities could be regulated by, or associated with, the 
Table $3 \mathrm{~K}^{+}$channels and transporters involved in xylem $\mathrm{K}^{+}$loading

\begin{tabular}{|c|c|c|}
\hline $\mathrm{K}^{+}$channels/transporters & Species & References \\
\hline NRT1.5/NPF7.3 $\mathrm{H}^{+} / \mathrm{K}^{+}$antiporter & Arabidopsis thaliana & Li et al. 2017 \\
\hline KUP7 $\mathrm{K}^{+}$transporter & Arabidopsis thaliana & Han et al. 2016 \\
\hline AtSKOR & Arabidopsis thaliana & Gaymard et al. 1998, Rodenas et al. 2017 \\
\hline OsK5.2 outward Shaker $\mathrm{K}^{+}$channel & Oryza sativa & Nguyen et al. 2017 \\
\hline OsHAK1 transporter & Oryza sativa & Chen et al. 2015 \\
\hline OsHAK5 transporter & Oryza sativa & Yang et al. 2014 \\
\hline SISKOR & Solanum lycopersicum & Rodenas et al. 2017 \\
\hline
\end{tabular}

change in the cytosolic $\mathrm{Ca}^{2+}$ levels in plants' response to salt stress. Similar to $\mathrm{Ca}^{2+}$ signature, $\mathrm{H}_{2} \mathrm{O}_{2}$ signature is another known signalling event in salt stressed plants. CIPK24 interacts with catalases and a $\mathrm{H}_{2} \mathrm{O}_{2}$ signalling protein NDPK2 (nucleoside diphosphate kinase2) (Verslues et al. 2007), suggesting a possible casual linkage between HAK/KUP activities and ROS signalling events in salt stressed plants. Onset of salt stress results in an elevation of cytosolic $\mathrm{Ca}^{2+}$, which could in turn activates CBL calcium sensors and thus CIPKs, leads to an activation of HAK/KUP activities or possible perturbance of $\mathrm{H}_{2} \mathrm{O}_{2}$ signalling. These observations suggest a possible casual relationship between $\mathrm{HAK} / \mathrm{KUP}$ mediated high-affinity $\mathrm{K}^{+}$transport and $\mathrm{Ca}^{2+}$ signature and ROS signalling (Fig. 2). Also, Raf-like kinase ILK1 interacts with and promotes HAK5 accumulation under osmotic and salt stress conditions in Arabidopsis (Brauer et al. 2016).

Xylem $\mathrm{K}^{+}$loading and unloading in salt stressed plants

$\mathrm{K}^{+}$absorbed by roots from soil is transferred to shoot, even under $\mathrm{K}^{+}$deprivation e.g. salt stress. Under nonsaline conditions, xylem $\mathrm{K}^{+}$loading can be mediated by passive transport. Shabala et al. (2010) showed that $\mathrm{NaCl}$-induced $\mathrm{K}^{+}$efflux from the xylem parenchyma tissue in barley roots correlated with membrane depolarization and was suppressed by $\mathrm{TEA}^{+}$but not $\mathrm{Gd}^{3+}$. This was interpreted as evidence for the operation of depolarization-activated $\mathrm{K}^{+}$-selective (e.g. SKOR) channels that activate in a time-dependent manner at membrane potentials slightly positive of the Nernst potential of $\mathrm{K}^{+}\left(\mathrm{E}_{\mathrm{K}}\right)$ (Gaymard et al. 1998). However, channel-mediated xylem $\mathrm{K}^{+}$loading may be not thermodynamically feasible under all conditions. Under control conditions, the membrane potential of barley stellar root cells was $-120 \mathrm{mV}$, while xylem sap $\left[\mathrm{K}^{+}\right]$ was between 3 and $7 \mathrm{mM}$, depending on calcium level in the growth media (Shabala et al. 2010). Thus, SKORmediated xylem $\mathrm{K}^{+}$loading under these conditions will require cytosolic $\left[\mathrm{K}^{+}\right]$to exceed $300 \mathrm{mM}$. This is well above the cytosolic $\left[\mathrm{K}^{+}\right]$values reported in the literature. Thus, under such conditions active xylem $\mathrm{K}^{+}$loading mechanisms may be required. HAK/KUP transporters are the most likely candidates for this role. Another candidate could be the NRT1.5 $\mathrm{H}^{+} / \mathrm{K}^{+}$antiporter ( $\mathrm{Li}$ et al. 2017). It has been confirmed that the presence of NRT1.5 antiporter in roots is important for root-to-shoot translocation of $\mathrm{K}^{+}$(Drechsler et al. 2015), and this NRT1.5 antiporter can supress nitrate starvationinduced leaf senescence by modulating foliar $\mathrm{K}^{+}$level (Meng et al. 2016). Mutation of NRT1.5 antiporters results in a remarkable defect in $\mathrm{K}^{+}$translocation from root to shoot, especially under low $\mathrm{K}^{+}$conditions $(\mathrm{Li}$ et al. 2017). Table 3 summarizes identified $\mathrm{K}^{+}$channels and transporters involved in the xylem $\mathrm{K}^{+}$loading (Gaymard et al. 1998; Yang et al. 2014; Chen et al. 2015; Han et al. 2016; Nguyen et al. 2017; Rodenas et al. 2017; Li et al. 2017).

As discussed above, plasma membrane is depolarized under salinity condition (at least at the early stages) and, thus, suppresses the activity of hyperpolarization activated AKT channels. In this case, xylem $\mathrm{K}^{+}$loading should be executed by voltage independent channels/ transporters e.g. KUP7 transporters (Han et al. 2016) or depolarization activated $\mathrm{K}^{+}$channels/transporters e.g. SKOR (Gaymard et al. 1998; Rodenas et al. 2017). The Shaker-like outward $\mathrm{K}^{+}$rectifying SKOR channel is expressed in the pericycle and the xylem parenchyma in roots (Gaymard et al. 1998). This channel is sensitive to $\mathrm{H}_{2} \mathrm{O}_{2}$ (Garcia-Mata et al. 2010), suggesting a probable linkage between salt stress ROS signalling and xylem $\mathrm{K}^{+}$ 
loading in salt stressed plants. Upon the acute depolarization of plasma membrane induced by salinity, SKOR in xylem parenchyma cells can be rapidly activated to mediate $\mathrm{K}^{+}$loading xylem. After the plasma membrane potential is restored by increased $\mathrm{H}^{+}$-ATPase activity, SKOR mediation of $\mathrm{K}^{+}$release from root stelar cells to xylem by membrane depolarization is suppressed. Then, accumulated ROS under salinity could in turn activate SKOR channels to allow xylem $\mathrm{K}^{+}$loading. This may require a highly coordinated mechanism to ensure efficient xylem $\mathrm{K}^{+}$loading in salt stressed plants. However, patch-clamp experiments of barley stellar tissue suggested that SKOR plays a little role in xylem $\mathrm{K}^{+}$loading under stress conditions (Shabala et al. 2010), implying involvement of some other transporters. One of the possible candidates may be HAK/KUP transporters. KUP7 showed a strong expression in root stelar tissues (Han et al. 2016). However, operation of $\mathrm{HAK} / \mathrm{KUP} \mathrm{K} \mathrm{K}^{+} / \mathrm{H}^{+}$ symporters relies on electrochemical $\mathrm{H}^{+}$gradients across the plasma membrane that require ATP-dependent $\mathrm{H}^{+}$ pumping. At the same time, a reduction of ATP content is always observed in salt stressed plants (Ma et al. 2010; Wu et al. 2018b; Yu et al. 2018), limiting involvement of $\mathrm{HAK} / \mathrm{KUP}$ transporters in xylem $\mathrm{K}^{+}$loading in salt stressed plants. Besides above mentioned SKOR and HAK/KUP transporters, NORC (non-selective outward rectifying channels in xylem parenchyma cells), which is permeable to both $\mathrm{Na}^{+}$and $\mathrm{K}^{+}$, could be another candidate involved in xylem $\mathrm{K}^{+}$loading in salt stressed plants (de Boer and Wegner 1997; De Boer 1999; Zepeda-Jazo et al. 2008; Shabala et al. 2010). However, due to NORC's ability to mediate $\mathrm{Na}^{+}$influx and $\mathrm{K}^{+}$efflux, tolerant barley varieties show significantly lower NORC activity in root epidermal protoplasts than sensitive counterparts under salt stress (Zepeda-Jazo et al. 2008), suggesting that NORC might not be a good candidate for xylem $\mathrm{K}^{+}$loading in salt stressed plants.

$\mathrm{K}^{+}$unloading in leaves also affects the distribution of $\mathrm{K}^{+}$in plants. Compared with $\mathrm{K}^{+}$loading, our knowledge of the mechanisms controlling $\mathrm{K}^{+}$unloading in leaves is still limited. One of the channels involved in this process could be $\mathrm{K}^{+}$inward rectifying channels e.g. AKT and KAT channels. For example, besides root epidermis, OsAKT1 show strong localization in the xylem ( $\mathrm{Li}$ et al. 2014), suggesting that besides its role in $\mathrm{K}^{+}$uptake from soil, it might also involve in xylem $\mathrm{K}^{+}$unloading. Furthermore, CHX14, a plasma membrane low affinity $\mathrm{K}^{+}$efflux transporter, has been proposed to export high concentration of $\mathrm{K}^{+}$out of xylem into xylem parenchyma cells (Zhao et al. 2015). Besides $\mathrm{K}^{+}$ unloading through channels and/or transporters, Botha et al. (2008) found that xylem unloading of membraneimpermeant probes could only occur through the xylem vessel-xylem parenchyma pit membranes, suggesting that endocytosis across xylem vessel-xylem parenchyma pit membranes could be another complementary pathway for $\mathrm{K}^{+}$unloading. This mechanism may be essential under saline conditions, when transport through transporters or channels could be compromised by depolarized plasma membrane and limited ATP. Also, salinity stress is known to induce bulk endocytosis in plant cell (Leshem et al. 2007; Li et al. 2011; Baral et al. 2015a, b; Garcia de la Garma et al. 2015; Zwiewka et al. 2015), suggesting the possible complementary role of the endocytosis pathway in $\mathrm{K}^{+}$unloading in salt stressed plants.

Phloem $\mathrm{K}^{+}$recirculation in salt stressed plants

Besides xylem $\mathrm{K}^{+}$loading and unloading, $\mathrm{K}^{+}$recirculation through the phloem is important to maintain $\mathrm{K}^{+}$ homeostasis in plant roots. This could be very likely a case for plants under salt stress since root $\mathrm{K}^{+}$uptake is disrupted. For example, under saline condition, xylem loading of $\mathrm{K}^{+}$from flag leaves into developing fruits might be impaired due to the decreased transpiration stream. Phloem recirculation of $\mathrm{K}^{+}$might contribute in fulfilling this gap to help finishing a complete life cycle. As a highly mobile nutrient in phloem, a large amount of $\mathrm{K}^{+}$delivered to the shoot is returned back to the root (Marschner et al. 1996). Armstrong and Kirkby (1979) calculated that about $20 \%$ of the upward flux of $\mathrm{K}^{+}$in xylem stream was resulted from recirculated $\mathrm{K}^{+}$via phloem of tomato plants. In some species e.g. barley and castor bean, the portion of recirculated $\mathrm{K}^{+}$from phloem to root can be up to $85 \%$ (Jeschke et al. 1991; Marschner et al. 1996). The physiological rationale behind $\mathrm{K}^{+}$cycling via phloem is a feedback control of the radial $\mathrm{K}^{+}$uptake by roots. The voltage-gated hyperpolarization activated AKT2 $\mathrm{K}^{+}$channels are known to play a role in phloem loading and unloading (De Schepper et al. 2013; Sklodowski et al. 2017), and their activity could be suppressed in salt stressed plants since plant cell plasma membrane is significantly depolarized, at least at the early stage of salinity stress. The expression of $A K T 2$ has been shown to decrease in wild-type rice plants under salt stress (Schmidt et al. 2013). Thus, not AKT but other types of $\mathrm{K}^{+}$channels and transporters 
should play a main role in phloem $\mathrm{K}^{+}$recirculation of salt stressed plants. KZM1 $\left(\mathrm{K}^{+}\right.$channel Zea mays 1$)$ and VFK1 (Vicia faba $\mathrm{K}^{+}$channel 1) Shaker-type channels were shown to mediate $\mathrm{K}^{+}$uptake into the phloem of maize (Philippar et al. 2003) and $\mathrm{K}^{+}$unloading from phloem (Ache et al. 2001), respectively. Su et al. (2002) showed low expression of McHAK4 in phloem cells in non-stressed ice plant (Mesembryanthemum crystallinum) leaves and that its expression was stimulated predominantly in the phloem cells in salt stressed leaves. Thus, regulation of phloem $\mathrm{K}^{+}$recirculation in salt stressed plants could be likely achieved by manipulating the expression pattern and activity of Shaker-type $\mathrm{K}^{+}$channels or HAK/KUP transporters.

As mentioned early, unlike a strong and positive correlation observed between the amounts of $\mathrm{K}^{+}$ retained in shoots or leaves in common crops and their salinity tolerance threshold, a negative correlation exists for the total root content (Fig. 1b). Moreover, the overall root $\mathrm{K}^{+}$content increased under saline conditions in some sensitive species such as Vicia faba (Hamada 1994; Bulut and Akınc1 2010) and tomato (Ai-Rawahy et al. 1992). A very significant negative correlation ( $r=$ $0.86, P=0.017<0.05)$ is observed between the relative changes in the retained root $\mathrm{K}^{+}$and changes in the shoot $\mathrm{K}^{+}$content (Fig. 1c). One of the possible explanations for this relationship might be an increased amount of $\mathrm{K}^{+}$ returning to roots via phloem, on the expense of the shoot. This is consistent with observations that phloem recirculation rate of $\mathrm{K}^{+}$is decreased in salt stressed tolerant barley (Wolf and Dieter Jeschke 1987) but is increased in salt-sensitive pea (Wang et al. 2016b) plants. This suggests that control of $\mathrm{K}^{+}$recirculation in the phloem could represent another mechanism for plant salt tolerance. Surprisingly, this trait has never been targeted by plant breeders, despite its obvious essentiality for plant energy balance. Indeed, a failure to coordinate $\mathrm{K}^{+}$signals between root and shoot could induce a futile cycle of phloem $\mathrm{K}^{+}$recirculation, reducing energy availability allocated towards plant growth.

\section{Replenishing cytosolic $\mathrm{K}^{+}$from the vacuolar pool}

Once signalling via $\mathrm{K}^{+}$is completed, plants need to restore cytosolic $\mathrm{K}^{+}$concentration back to pre-stress level, to enable normal cell metabolism. Given that the operation of AKT uptake channels may be compromised by depolarized membrane potential, plants may rely on $\mathrm{HAK} / \mathrm{KUP}$ family of $\mathrm{K}^{+} / \mathrm{H}^{+}$symporters.
Because their transport capacity is about three orders of magnitude lower than that for ion channels (Gadsby 2019), it is unlikely that the cell will be able to rapidly compensate GORK channel-mediated $\mathrm{K}^{+}$loss by operation of existing HAK/KUP transporters. As this HAK/ KUP based process is relatively slow (hours timescale), the rapid termination of $\mathrm{K}^{+}$signalling plants needs to rely on $\mathrm{K}^{+}$supply from internal stores. Indeed, higher TPC1 (SV channel) transcript levels were reported in plants grown under saline conditions (Choi et al. 2014). Overexpression of a vacuolar two pore $\mathrm{K}^{+}$channel PeTPK1 in tobacco cells resulted in less $\mathrm{K}^{+}$loss and higher biomass than the wild type cells under salt stress (Wang et al. 2013a). The largest $\mathrm{K}^{+}$depot in the cell is a vacuole. Thus, vacuolar $\mathrm{K}^{+}$release should represent an important component of stress-induced $\mathrm{K}^{+}$signalling and cytosolic $\mathrm{K}^{+}$mechanism.

Potassium release from vacuoles may be mediated by three types of tonoplast channels: $\mathrm{K}^{+}$-selective TPK (two pore potassium) channels, and slow- (SV) and fast- (FV) activating non-selective cations channels (Pottosin et al. 2003; Gobert et al. 2007; Pottosin and Dobrovinskaya 2014). Isayenkov et al. (2015) found that overexpression of TPKa increased salt tolerance in rice. Indeed, OSTPKa is upregulated by 4 -folds in salt stressed rice plants, whereas no significant change of OsTPKb was found (Isayenkov et al. 2011). Ahmad et al. (2016a) also showed that overexpression of TPKb channel increased the ratio of $\mathrm{K}^{+}$between the cytosol and the vacuole. A salt stress induced stimulation of TPK1 channel has been shown in Arabidopsis (Latz et al. 2013) and tobacco (Hamamoto et al. 2008). The FV and SV channels may act as "safety valves" controlling $\mathrm{K}^{+}$distribution between cytosol and vacuole (Pottosin and Dobrovinskaya 2014). Application of salt triggers the release of $\mathrm{Ca}^{2+}$ into cytosol and thus contributes to the activation of TPC1 in Arabidopsis (Evans et al. 2016). An enhanced salt stress tolerance and increased leaf chlorophyll content were observed in TPC1 (SV channel) overexpression line (Choi et al. 2014). Interestingly, a 6-folds' transient increase of TPC1 transcript levels was found in salt stressed Arabidopsis shoots, whereas a sustained decrease was found in salt stressed roots (Choi et al. 2014). BonalesAlatorre et al. (2013) showed that reduced FV and SV channel activity in salt stressed halophyte quinoa is essential to prevent a futile $\mathrm{Na}^{+}$leak from the vacuole to the cytosol followed by its sequestration by NHX exchanger. Having SV and FV channels active may be 
important to replenish cytosolic $\mathrm{K}^{+}$depletion; however, it comes with a danger of having uncontrollable $\mathrm{Na}^{+}$ leak (Fig. 2). So, the ideal scenario is to increase $\mathrm{K}^{+}$ selective TPK activity but decrease $\mathrm{K}^{+}$non-selective $\mathrm{SV}$ (TPC1) activity at the same time. TPK1 channel is known to be activated by 14-3-3 proteins (Latz et al. 2007), whereas 14-3-3 proteins drastically reduces the SV channel currents (Van den Wijngaard et al. 2001; Latz et al. 2007). This suggests a possibility of coordination between TPK and TPC channel activity by 14-33 proteins. For example, by increasing expression of 14-3-3 proteins and their delivery to tonoplast, TPK channel can be activated alongside with the inactivation of TPC channels, leading to replenishing cytosolic $\mathrm{K}^{+}$ from the vacuolar pool, while avoiding $\mathrm{Na}^{+}$back leak to the cytosol from the vacuole.

How big is the vacuolar buffering $\mathrm{K}^{+}$capacity? The reported concentrations of vacuolar $\mathrm{K}^{+}$in plant cells are usually in the range of 120 to $250 \mathrm{mM}$ (Walker et al. 1996; Cuin et al. 2003). At the same time, cytosolic $\mathrm{K}^{+}$ concentrations are approximately $100 \mathrm{mM}$ and drop under saline conditions to $40-50 \mathrm{mM}$ (Cuin et al. 2003; Shabala et al. 2006). From thermodynamical point of view, vacuolar $\mathrm{K}^{+}$concentration cannot be lower than the cytosolic one, if a passive loading mechanisms is envisaged. Thus, to be used as a cytosolic $\mathrm{K}^{+}$ pool buffer, vacoular concentration can drop by about $200 \mathrm{mM}$ (from 250 to $50 \mathrm{mM}$ ). Assuming a typical cell being $40 \mu \mathrm{m}$ in diameter, and a vacuole occupying $90 \%$ of the cell volume, then the vacuolar volume is $3.35 \times$ $10^{-14} \mathrm{~m}^{3}$, and the cellular surface area is $5 \times 10^{-9} \mathrm{~m}^{2}$. Hence, the amount of $\mathrm{K}^{+}$the vacuole can give away by dropping its $\mathrm{K}^{+}$content by $200 \mathrm{mM}$ is $6 \times 10^{-12} \mathrm{~mol}$. At the same time, the reported mean net $\mathrm{K}^{+}$efflux from plant roots are in the range of 50 to $200 \mathrm{nmol} \mathrm{m}^{-2} \mathrm{~s}^{-1}$ (Chen et al. 2007; Cuin et al. 2009; Sun et al. 2012). Thus, the amount of time the cell can "buy" relying on vacuolar $\mathrm{K}^{+}$pool will be:

$T=\frac{A}{F \times S}$

Where $\mathrm{T}=$ time the buffering can sustain $(\mathrm{sec}) ; \mathrm{A}=$ amount of vacuolar $\mathrm{K}^{+}$available to buffer cytosolic $\mathrm{K}^{+}$ loss (mol); $\mathrm{F}=$ mean net $\mathrm{K}^{+}$efflux across the plasma membrane $\left(\mathrm{mol} \mathrm{m} \mathrm{s}^{-2}\right) ; \mathrm{S}=$ cell surface area $\left(\mathrm{m}^{2}\right)$.

Putting appropriate numbers into the equation above, one can yield values between 100 and $400 \mathrm{~min}$ (or $\sim 1.5$ to $7 \mathrm{~h}$ ), depending on the accepted flux values. Obviously, these numbers are not big enough to be considered seriously from the perspective of long-term plant adaptation. However, several hours of buffering may be sufficient to complete the signalling process and increase the amount of transcripts for high affinity transporters, to increase $\mathrm{K}^{+}$uptake and restore the cellular $\mathrm{K}^{+}$ pool volume.

\section{Concluding remarks}

Compared with sodium, potassium has always been treated as a "Cinderella", in terms of its role in the overall salinity stress tolerance. This situation has started to change in the last $10-15$ years, after discovering the essential signalling role of $\mathrm{K}^{+}$in plant adaptive responses to salinity (in addition to its merely rational role). However, in practical terms, $\mathrm{K}^{+}$-related traits have never been targeted in breeding programs, except at the whole-plant level. This is clearly not good enough, given the high specificity of tissue- and organelle- dependent regulation of $\mathrm{K}^{+}$transport and homeostasis. From this point of view, $\mathrm{K}^{+}$-related traits represent a previously untapped resource for breeders, and we are confident that the next decade will witness a major shift towards research on $\mathrm{K}^{+}$as a key determinant of plant salinity tissue tolerance. After all, salinity is not all about sodium.

Acknowledgements We thank A/Prof Zhong-Hua Chen from Western Sydney University for his suggestions. This work was supported by a $\mathrm{PhD}$ scholarship provided by University of Tasmania (185466S9A) to WH and the Open Fund of State Key Laboratory of Tea Plant Biology and Utilization at Anhui Agricultural University (SKLTOF20170112) to WH and ZX; a grant from the Australian Research Council and Grain Research and Development Corporation Grants to SS; and a funding from Foshan University to SS.

\section{References}

Abdelaziz ME, Kim D, Ali S, Fedoroff NV, al-Babili S (2017) The endophytic fungus Piriformospora indica enhances Arabidopsis thaliana growth and modulates $\mathrm{Na}^{+} / \mathrm{K}^{+}$homeostasis under salt stress conditions. Plant Sci 263:107-115

Ache P, Becker D, Deeken R, Dreyer I, Weber H, Fromm J, Hedrich R (2001) VFK1, a Vicia faba $\mathrm{K}^{+}$channel involved in phloem unloading. Plant J 27:571-580

Ahmad I, Devonshire J, Mohamed R, Schultze M, Maathuis FJM (2016a) Overexpression of the potassium channel $\mathrm{TPKb}$ in small vacuoles confers osmotic and drought tolerance to rice. New Phytol 209:1040-1048 
Ahmad I, Mian A, Maathuis FJM (2016b) Overexpression of the rice AKT1 potassium channel affects potassium nutrition and rice drought tolerance. J Exp Bot 67:2689-2698

Ai-Rawahy SA, Stroehlein JL, Pessarakli M (1992) Dry-matter yield and nitrogen-15, $\mathrm{Na}^{+}, \mathrm{cl}^{-}$, and $\mathrm{K}^{+}$content of tomatoes under sodium chloride stress. J Plant Nutr 15:341-358

Ali Z, Park HC, Ali A, Oh DH, Aman R, Kropornicka A, Hong H, Choi W, Chung WS, Kim WY, Bressan RA, Bohnert HJ, Lee SY, Yun DJ (2012) TsHKT1;2, a HKT1 homolog from the extremophile Arabidopsis relative Thellungiella salsuginea, shows $\mathrm{K}^{+}$specificity in the presence of $\mathrm{NaCl}$. Plant Physiol 158:1463-1474

Ali A, Park HC, Aman R et al (2013) Role of HKT1 in Thellungiella salsuginea, a model extremophile plant. Plant Signal Behav 8:10-13

Anschütz U, Becker D, Shabala S (2014) Going beyond nutrition: regulation of potassium homoeostasis as a common denominator of plant adaptive responses to environment. J Plant Physiol 171:670-687

Armstrong MJ, Kirkby EA (1979) Estimation of potassium recirculation in tomato plants by comparison of the rates of potassium and calcium accumulation in the tops with their fluxes in the xylem stream. Plant Physiol 63:1143-1148

Baral A, Irani NG, Fujimoto M, Nakano A, Mayor S, Mathew MK (2015a) Salt-induced remodeling of spatially restricted clathrin-independent endocytic pathways in Arabidopsis root. Plant Cell 27:1297-1315

Baral A, Shruthi KS, Mathew MK (2015b) Vesicular trafficking and salinity responses in plants. IUBMB Life 67:677-686

Bonales-Alatorre E, Shabala S, Chen ZH, Pottosin I (2013) Reduced tonoplast fast-activating and slow-activating channel activity is essential for conferring salinity tolerance in a facultative halophyte, quinoa. Plant Physiol 162:940-952

Bose J, Xie Y, Shen W, Shabala S (2013) Haem oxygenase modifies salinity tolerance in Arabidopsis by controlling $\mathrm{K}^{+}$ retention via regulation of the plasma membrane $\mathrm{H}^{+}$-ATPase and by altering SOS1 transcript levels in roots. J Exp Bot 64: $471-481$

Bose J, Shabala L, Pottosin I et al (2014) Kinetics of xylem loading, membrane potential maintenance, and sensitivity of $\mathrm{K}^{+}$-permeable channels to reactive oxygen species: physiological traits that differentiate salinity tolerance between pea and barley. Plant Cell Environ 37:589-600

Botha CEJ, Aoki N, Scofield GN, Liu L, Furbank RT, White RG (2008) A xylem sap retrieval pathway in rice leaf blades: evidence of a role for endocytosis? J Exp Bot 59:2945-2954

Brauer EK, Ahsan N, Dale R et al (2016) The Raf-like kinase ILK1 and the high affinity $\mathrm{K}^{+}$transporter HAK5 are required for innate immunity and abiotic stress response. Plant Physiol $171: 1470-1484$

Bulut F, Akıncı Ș (2010) The effect of salinity on growth and nutrient composition in broad bean (Vicia faba L.) seedlings. Fresenius Environ Bull 19:2901-2910

Chakraborty K, Bose J, Shabala L, Eyles A, Shabala S (2016a) Evaluating relative contribution of osmotolerance and tissue tolerance mechanisms toward salinity stress tolerance in three Brassica species. Physiol Plant 158:135-151

Chakraborty K, Bose J, Shabala L, Shabala S (2016b) Difference in root $\mathrm{K}^{+}$retention ability and reduced sensitivity of $\mathrm{K}^{+}$permeable channels to reactive oxygen species confer differential salt tolerance in three Brassica species. J Exp Bot 67:4611-4625

Chen Z, Newman I, Zhou M et al (2005) Screening plants for salt tolerance by measuring $\mathrm{K}^{+}$flux: a case study for barley. Plant Cell Environ 28:1230-1246

Chen Z, Pottosin II, Cuin TA, Fuglsang AT, Tester M, Jha D, Zepeda-Jazo I, Zhou M, Palmgren MG, Newman IA, Shabala S (2007) Root plasma membrane transporters controlling $\mathrm{K}^{+} / \mathrm{Na}^{+}$homeostasis in salt-stressed barley. Plant Physiol 145:1714-1725

Chen G, Hu Q, Luo L, Yang T, Zhang S, Hu Y, Yu L, Xu G (2015) Rice potassium transporter OsHAK1 is essential for maintaining potassium-mediated growth and functions in salt tolerance over low and high potassium concentration ranges. Plant Cell Environ 38:2747-2765

Chen J, Zhang H, Zhang X, Tang M (2017) Arbuscular mycorrhizal symbiosis alleviates salt stress in black locust through improved photosynthesis, water status, and $\mathrm{K}^{+} / \mathrm{Na}^{+}$homeostasis. Front Plant Sci 8:1-14

Choi W-G, Toyota M, Kim S-H, Hilleary R, Gilroy S (2014) Salt stress-induced $\mathrm{Ca}^{2+}$ waves are associated with rapid, longdistance root-to-shoot signaling in plants. Proc Natl Acad Sci 111:6497-6502

Cuin TA, Miller AJ, Laurie SA, Leigh RA (2003) Potassium activities in cell compartments of salt-grown barley leaves. J Exp Bot 54:657-661

Cuin TA, Shabala S (2007) Compatible solutes reduce ROSinduced pottasium efflux in Arabidopsis roots. Plant Cell Environ 30:875-885

Cuin TA, Betts SA, Chalmandrier R, Shabala S (2008) A root's ability to retain $\mathrm{K}^{+}$correlates with salt tolerance in wheat. $\mathrm{J}$ Exp Bot 59:2697-2706

Cuin TA, Tian Y, Betts SA, Chalmandrier R, Shabala S (2009) Ionic relations and osmotic adjustment in durum and bread wheat under saline conditions. Funct Plant Biol 36:1110 1119

Cuin TA, Zhou M, Parsons D, Shabala S (2012) Genetic behaviour of physiological traits conferring cytosolic $\mathrm{K}^{+} / \mathrm{Na}^{+}$homeostasis in wheat. Plant Biol 14:438-446

Dasgan HY, Aktas H, Abak K, Cakmak I (2002) Determination of screening techniques to salinity tolerance in tomatoes and investigation of genotype responses. Plant Sci 163:695-703

De Boer AH (1999) Potassium translocation into the root xylem. Plant Biol 1:36-45

De Boer A, Wegner L (1997) Regulatory mehanisms of ion channels in xylem parenchya cells. J Exp Bot 48:441-449

De Schepper V, De Swaef T, Bauweraerts I, Steppe K (2013) Phloem transport: a review of mechanisms and controls. J Exp Bot 64:4839-4850

Deinlein U, Stephan AB, Horie T, Luo W, Xu G, Schroeder JI (2014) Plant salt-tolerance mechanisms. Trends Plant Sci 19: 371-379

Demidchik V (2018) ROS-activated ion channels in plants: biophysical characteristics, physiological functions and molecular nature. Int J Mol Sci 19:1263

Demidchik V, Maathuis FJM (2007) Physiological roles of nonselective cation channels in plants: from salt stress to signalling and development. New Phytol 175:387-404

Demidchik V, Cuin T a, Svistunenko D et al (2010) Arabidopsis root $\mathrm{K}^{+}$-efflux conductance activated by hydroxyl radicals: 
single-channel properties, genetic basis and involvement in stress-induced cell death. J Cell Sci 123:1468-1479

Demidchik V, Straltsova D, Medvedev SS, Pozhvanov GA, Sokolik A, Yurin V (2014) Stress-induced electrolyte leakage: the role of $\mathrm{K}^{+}$-permeable channels and involvement in programmed cell death and metabolic adjustment. J Exp Bot 65:1259-1270

Dennison KL, Robertson WR, Lewis BD, Hirsch RE, Sussman MR, Spalding EP (2001) Functions of AKT1 and AKT2 potassium channels determined by studies of single and double mutants of Arabidopsis. Plant Physiol 127:10121019

Dinneny JR, Long Ta, Wang JY et al (2008) Cell identity mediates the response of Arabidopsis roots to abiotic stress. Science 320:942-946

Drechsler N, Zheng Y, Bohner A et al (2015) Nitrate-dependent control of shoot $\mathrm{K}$ homeostasis by NPF7.3/NRT1.5 and SKOR in Arabidopsis. Plant Physiol 169:2832-2847

Dreyer I, Uozumi N (2011) Potassium channels in plant cells. FEBS J 278:4293-4303

Dubos C, Huggins D, Grant GH, Knight MR, Campbell MM (2003) A role for glycine in the gating of plant NMDA-like receptors. Plant J 35:800-810

Essa TA (2002) Effect of salinity stress on growth and nutrient composition of three soybean (Glycine max L. Merrill) cultivars. J Agron Crop Sci 188:86-93

Evans MJ, Choi WG, Gilroy S, Morris RJ (2016) A ROS-assisted calcium wave dependent on the AtRBOHD NADPH oxidase and TPC1 cation channel propagates the systemic response to salt stress. Plant Physiol 171:1171-1784

Evans HJ, Sorger GJ (1966) Role of mineral elements with emphasis on the univalent cations. Annu Rev Plant Physiol 17: 47-76

Fischer RA (1968) Stomatal opening: role of potassium uptake by guard cells. Science 160:784-785

Fita A, Rodríguez-Burruezo A, Boscaiu M et al (2015) Breeding and domesticating crops adapted to drought and salinity: a new paradigm for increasing food production. Front Plant Sci 6:978

Forde BG (2014) Glutamate signalling in roots. J Exp Bot 65:779787

Gadsby DC (2009) Ion channels versus ion pumps: the principal difference, in principle. Nat Rev Mol Cell Biol 10:344-352

Gajdanowicz P, Michard E, Sandmann M, Rocha M, Correa LGG, Ramirez-Aguilar SJ, Gomez-Porras JL, Gonzalez W, Thibaud JB, van Dongen JT, Dreyer I (2011) Potassium $\left(\mathrm{K}^{+}\right)$gradients serve as a mobile energy source in plant vascular tissues. Proc Natl Acad Sci U S A 108:864-869

Gao Y, Lu Y, Wu M et al (2016) Ability to remove $\mathrm{Na}^{+}$and retain $\mathrm{K}^{+}$correlates with salt tolerance in two maize inbred lines seedlings. Front Plant Sci 7:1-15

Garcia de la Garma J, Fernandez-Garcia N, Bardisi E, Pallol B, Asensio-Rubio JS, Bru R, Olmos E (2015) New insights into plant salt acclimation: the roles of vesicle trafficking and reactive oxygen species signalling in mitochondria and the endomembrane system. New Phytol 205:216-239

Garcia-Mata C, Wang J, Gajdanowicz P, Gonzalez W, Hills A, Donald N, Riedelsberger J, Amtmann A, Dreyer I, Blatt MR (2010) A minimal cysteine motif required to activate the SKOR $\mathrm{K}^{+}$channel of arabidopsis by the reactive oxygen species $\mathrm{H}_{2} \mathrm{O}_{2}$. J Biol Chem 285:29286-29294
Gaymard F, Pilot G, Lacombe B, Bouchez D, Bruneau D, Boucherez J, Michaux-Ferrière N, Thibaud JB, Sentenac H (1998) Identification and disruption of a plant shaker-like outward channel involved in $\mathrm{K}^{+}$release into the xylem sap. Cell 94:647-655

Genc Y, McDonald GK, Tester M (2007) Reassessment of tissue $\mathrm{Na}^{+}$concentration as a criterion for salinity tolerance in bread wheat. Plant Cell Environ 30:1486-1498

Gierth M, Maser P, Schroeder JI (2005) The potassium transporter AtHAK5 functions in $\mathrm{K}^{+}$deprivation-induced high-affinity $\mathrm{K}^{+}$uptake and AKT1 $\mathrm{K}^{+}$channel contribution to $\mathrm{K}^{+}$uptake kinetics in Arabidopsis roots. Plant Physiol 137:1105-1114

Glusker JP (2006) Cation-activated enzymes. In: Encyclopedia of inorganic chemistry. John Wiley \& Sons, Ltd, Chichester, UK, pp 1-9

Gobert A, Isayenkov S, Voelker C, Czempinski K, Maathuis FJM (2007) The two-pore channel TPK1 gene encodes the vacuolar $\mathrm{K}^{+}$conductance and plays a role in $\mathrm{K}^{+}$homeostasis. Proc Natl Acad Sci 104:10726-10731

Grabov A (2007) Plant KT/KUP/HAK potassium transporters: single family - multiple functions. Ann Bot 99:1035-1041

Hamada AM (1994) Effect of $\mathrm{NaCl}$ salinity on growth, pigment and mineral element contents, and gas exchange of broad bean and pea plants. Biol Plant 36:75-81

Hamamoto S, Marui J, Matsuoka K, Higashi K, Igarashi K, Nakagawa T, Kuroda T, Mori Y, Murata Y, Nakanishi Y, Maeshima M, Yabe I, Uozumi N (2008) Characterization of a tobacco TPK-type $\mathrm{K}^{+}$channel as a novel tonoplast $\mathrm{K}^{+}$ channel using yeast tonoplasts. J Biol Chem 283:1911-1920

Han M, Wu W, Wu WH, Wang Y (2016) Potassium transporter KUP7 is involved in $\mathrm{K}^{+}$acquisition and translocation in Arabidopsis root under $\mathrm{K}^{+}$-limited conditions. Mol Plant 9: 437-446

Hanin M, Ebel C, Ngom M et al (2016) New insights on plant salt tolerance mechanisms and their potential use for breeding. Front Plant Sci 7:1-17

Hauser F, Horie T (2010) A conserved primary salt tolerance mechanism mediated by HKT transporters: a mechanism for sodium exclusion and maintenance of high $\mathrm{K}^{+} / \mathrm{Na}^{+}$ratio in leaves during salinity stress. Plant Cell Environ 33:552565

Hedrich R, Shabala S (2018) Stomata in a saline world. Curr Opin Plant Biol (doi:10.1016/j.pbi.2018.07.015)

Horie T, Karahara I, Katsuhara M (2012) Salinity tolerance mechanisms in glycophytes: an overview with the central focus on rice plants. Rice 5:1-18

Huh GH, Damsz B, Matsumoto TK, Reddy MP, Rus AM, Ibeas JI, Narasimhan ML, Bressan RA, Hasegawa PM (2002) Salt causes ion disequilibrium-induced programmed cell death in yeast and plants. Plant J 29:649-659

Isayenkov S, Isner J, Maathuis FJM (2011) Membrane localization diversity of TPK channels and their physiological role. 12011204

Isayenkov SV, Mian A, Maathuis FJM (2015) The overexpression of gene encoding rice potassiun channel - OsTPKa increases the salt and drought tolerance of plants. Biotechnol Acta 8: 78-83

Jayakannan M, Bose J, Babourina O, Rengel Z, Shabala S (2013) Salicylic acid improves salinity tolerance in Arabidopsis by restoring membrane potential and preventing salt-induced $\mathrm{K}^{+}$ loss via a GORK channel. J Exp Bot 64:2255-2268 
Jeschke WD, Pate JS, Jeschke WD, Pate JS (1991) Cation and chloride partitioning through xylem and phloem within the whole plant of Ricinus communis L. under conditions of salt stress. J Exp Bot 42:1105-1116

Kavitha PG, Miller AJ, Mathew MK, Maathuis FJM (2012) Rice cultivars with differing salt tolerance contain similar cation channels in their root cells. J Exp Bot 63:3289-3296

Kerepesi I, Galiba G (2000) Osmotic and salt stress-induced alteration in soluble carbohydrate content in wheat seedlings. Crop Sci 40:482-487

Kiani-Pouya A, Roessner U, Jayasinghe NS, Lutz A, Rupasinghe T, Bazihizina N, Bohm J, Alharbi S, Hedrich R, Shabala S (2017) Epidermal bladder cells confer salinity stress tolerance in the halophyte quinoa and Atriplex species. Plant Cell Environ 40:1900-1915

Kim T-H, Böhmer M, Hu H, Nishimura N, Schroeder JI (2010) Guard cell signal transduction network: advances in understanding abscisic acid, $\mathrm{CO}_{2}$, and $\mathrm{Ca}^{2+}$ signaling. Annu $\mathrm{Rev}$ Plant Biol 61:561-591

Krumm M, Moazami V, Martin P (1990) Influence of potassium nutrition on concentrations of water soluble carbohydrates, potassium, calcium, and magnesium and the osmotic potential in sap extracted from wheat (Triticum aestivum) ears during preanthesis development. Plant Soil 124:281-285

Latz A, Becker D, Hekman M, Müller T, Beyhl D, Marten I, Eing C, Fischer A, Dunkel M, Bertl A, Rapp UR, Hedrich R (2007) TPK1, a $\mathrm{Ca}^{2+}$-regulated Arabidopsis vacuole twopore $\mathrm{K}^{+}$channel is activated by 14-3-3 proteins. Plant J 52: 449-459

Latz A, Mehlmer N, Zapf S, Mueller TD, Wurzinger B, Pfister B, Csaszar E, Hedrich R, Teige M, Becker D (2013) Salt stress triggers phosphorylation of the arabidopsis vacuolar $\mathrm{K}^{+}$ channel TPK1 by cal. Mol Plant 6:1274-1289

Leshem Y, Seri L, Levine A (2007) Induction of phosphatidylinositol 3-kinase-mediated endocytosis by salt stress leads to intracellular production of reactive oxygen species and salt tolerance. Plant J 51:185-197

Li J, Jiang A, Zhang W (2007) Salt stress-induced programmed cell death in rice root tip cells. J Integr Plant Biol 49:481-486

Li X, Wang X, Yang Y, Li R, He Q, Fang X, Luu DT, Maurel C, Lin J (2011) Single-molecule analysis of PIP2;1 dynamics and partitioning reveals multiple modes of Arabidopsis plasma membrane aquaporin regulation. Plant Cell 23:37803797

Li J, Long Y, Qi G-N, Li J, Xu ZJ, Wu WH, Wang Y (2014) The Os-AKT1 channel is critical for $\mathrm{K}^{+}$uptake in rice roots and is modulated by the rice CBL1-CIPK23 complex. Plant Cell 26:3387-3402

Li H, Yu M, Du X-Q et al (2017) NRT1.5/NPF7.3 functions as a proton-coupled $\mathrm{H}+/ \mathrm{K}+$ antiporter for $\mathrm{K}^{+}$loading into the xylem in Arabidopsis. Plant Cell 29:2016-2026

Livingston DP, Hincha DK, Heyer AG (2009) Fructan and its relationship to abiotic stress tolerance in plants. Cell $\mathrm{Mol}$ Life Sci 66:2007-2023

Lu K, Ding W, Zhu S, Jiang D (2016) Salt-induced difference between Glycine cyrtoloba and G. max in anti-oxidative ability and $\mathrm{K}^{+}$vs. $\mathrm{Na}^{+}$selective accumulation. Crop J 4: 129-138

Ma X, Deng L, Li J, Zhou X, Li N, Zhang D, Lu Y, Wang R, Sun J, Lu C, Zheng X, Fritz E, Hüttermann A, Chen S (2010) Effect of $\mathrm{NaCl}$ on leaf $\mathrm{H}^{+}$-ATPase and the relevance to salt tolerance in two contrasting poplar species. Trees 24:597-607

Ma L, Zhang H, Sun L, Jiao Y, Zhang G, Miao C, Hao F (2012) NADPH oxidase AtrbohD and AtrbohF function in ROSdependent regulation of $\mathrm{Na}^{+} / \mathrm{K}^{+}$homeostasis in Arabidopsis under salt stress. J Exp Bot 63:305-317

Maathuis FJM (2014) Sodium in plants: perception, signalling, and regulation of sodium fluxes. J Exp Bot 65:849-858

Maathuis FJM, Amtmann A (1999) $\mathrm{K}^{+}$nutrition and $\mathrm{Na}^{+}$toxicity : the basis of cellular $\mathrm{K}^{+} / \mathrm{Na}^{+}$ratios. Ann Bot 84:123-133

Marschner H, Kirkby EA, Cakmak I (1996) Effect of mineral nutritional status on shoot- root partitioning of photoassimilates and cycling of mineral nutrients. J Exp Bot 47:1255-1263

Meng S, Peng JS, He YN, Zhang GB, Yi HY, Fu YL, Gong JM (2016) Arabidopsis NRT1.5 mediates the suppression of nitrate starvation-induced leaf senescence by modulating foliar potassium level. Mol Plant 9:461-470

Michard E, Dreyer I, Lacombe B, Sentenac H, Thibaud JB (2005) Inward rectification of the AKT2 channel abolished by voltage-dependent phosphorylation. Plant J 44:783-797

Miller G, Suzuki N, Ciftci-Yilmaz S, Mittler R (2010) Reactive oxygen species homeostasis and signalling during drought and salinity stresses. Plant Cell Environ 33:453-467

Mittler R (2017) ROS are good. Trends Plant Sci 22:11-19

Munns R, Tester M (2008) Mechanisms of salinity tolerance. Annu Rev Plant Biol 59:651-681

Nguyen TH, Huang S, Meynard D, Chaine C, Michel R, Roelfsema MRG, Guiderdoni E, Sentenac H, Véry AA (2017) A dual role for the OsK5.2 ion channel in stomatal movements and $\mathrm{K}^{+}$loading into xylem sap. Plant Physiol 174:2409-2418

Nieves-Cordones M, Aleman F, Martinez V, Rubio F (2010) The Arabidopsis thaliana HAK5 $\mathrm{K}^{+}$transporter is required for plant growth and $\mathrm{K}^{+}$acquisition from low $\mathrm{K}^{+}$solutions under saline conditions. Mol Plant 3:326-333

Nieves-Cordones M, Aleman F, Martinez V, Rubio F (2014) $\mathrm{K}^{+}$ uptake in plant roots. The systems involved, their regulation and parallels in other organisms. J Plant Physiol 171:688-695

Nieves-Cordones M, Martinez V, Benito B, Rubio F (2016) Comparison between Arabidopsis and rice for main pathways of $\mathrm{K}^{+}$and $\mathrm{Na}^{+}$uptake by roots. Frontiers Plant Sci 7

Osakabe Y, Arinaga N, Umezawa T, Katsura S, Nagamachi K, Tanaka H, Ohiraki H, Yamada K, Seo SU, Abo M, Yoshimura E, Shinozaki K, Yamaguchi-Shinozaki K (2013) Osmotic stress responses and plant growth controlled by potassium transporters in Arabidopsis. Plant Cell 25:609624

Ou W, Mao X, Huang C et al (2018) Genome-wide identification and expression analysis of the KUP family under abiotic stress in cassava (Manihot esculenta Crantz). Front Physiol 9:1-11

Pan YJ, Liu L, Lin YC et al (2016) Ethylene antagonizes saltinduced growth retardation and cell death process via transcriptional controlling of ethylene-, BAG- and senescenceassociated genes in Arabidopsis. Front Plant Sci 7:1-10

Pavlovkin J, Novacky A, Ullrich-Eberius CI (1986) Membrane potential changes during bacteria-induced hypersensitive reaction. Physiol Mol Plant Pathol 28:125-135 
Petrov V, Hille J, Mueller-Roeber B, Gechev TS (2015) ROSmediated abiotic stress-induced programmed cell death in plants. Front Plant Sci 6:1-16

Philippar K, Büchsenschütz K, Abshagen M, Fuchs I, Geiger D, Lacombe B, Hedrich R (2003) The $\mathrm{K}^{+}$channel KZM1 mediates potassium uptake into the phloem and guard cells of the C4 grass Zea mays. J Biol Chem 278:16973-16981

Pottosin I, Dobrovinskaya O (2014) Non-selective cation channels in plasma and vacuolar membranes and their contribution to $\mathrm{K}^{+}$transport. J Plant Physiol 171:732-742

Pottosin II, Martínez-Estévez M, Dobrovinskaya OR, Muñiz J (2003) Potassium-selective channel in the red beet vacuolar membrane. J Exp Bot 54:663-667

Price MB, Jelesko J, Okumoto S (2012) Glutamate receptor homologs in plants: functions and evolutionary origins. Front Plant Sci 3:1-10

Ragel P, Ródenas R, García-Martín E et al (2015) CIPK23 regulates HAK5-mediated high-affinity $\mathrm{K}^{+}$uptake in Arabidopsis roots. Plant Physiol 169:2863-2873

Rodenas R, Francisco Garcia-Legaz M, Lopez-Gomez E et al (2017) $\mathrm{NO}_{3}{ }^{-}, \mathrm{PO}_{4}{ }^{3-}$ and $\mathrm{SO}_{4}{ }^{2-}$ deprivation reduced LKT1mediated low-affinity $\mathrm{K}^{+}$uptake and SKOR-mediated $\mathrm{K}^{+}$ translocation in tomato and Arabidopsis plants. Physiol Plant 160:410-424

Rodríguez-Navarro A (2000) Potassium transport in fungi and plants. Biochim Biophys Acta Rev Biomembr 1469:1-30

Rubio F, Fon M, Rodenas R et al (2014) A low $\mathrm{K}^{+}$signal is required for functional high-affinity $\mathrm{K}^{+}$uptake through HAK5 transporters. Physiol Plant 152:558-570

Sano T, Becker D, Ivashikina N, Wegner LH, Zimmermann U, Roelfsema MRG, Nagata T, Hedrich R (2007) Plant cells must pass a $\mathrm{K}^{+}$threshold to re-enter the cell cycle. Plant J 50: 401-413

Sano T, Kutsuna N, Becker D, Hedrich R, Hasezawa S (2009) Outward-rectifying $\mathrm{K}^{+}$channel activities regulate cell elongation and cell division of tobacco BY-2 cells. Plant J 57:55-64

Schmidt R, Mieulet D, Hubberten H-M, Obata T, Hoefgen R, Fernie AR, Fisahn J, San Segundo B, Guiderdoni E, Schippers JHM, Mueller-Roeber B (2013) SALTRESPONSIVE ERF1 regulates reactive oxygen speciesdependent signaling during the initial response to salt stress in rice. Plant Cell 25:2115-2131

Schmöckel SM, Garcia AF, Berger B et al (2015) Different NaClinduced calcium signatures in the arabidopsis thaliana ecotypes Col-0 and C24. PLoS One 10:1-9

Shabala S (2009) Salinity and programmed cell death: Unravelling mechanisms for ion specific signalling. J Exp Bot 60:709712

Shabala S (2017) Signalling by potassium: another second messenger to add to the list? J Exp Bot 68:4003-4007

Shabala S, Pottosin I (2014) Regulation of potassium transport in plants under hostile conditions: implications for abiotic and biotic stress tolerance. Physiol Plant 151:257-279

Shabala S, Demidchik V, Shabala L, Cuin TA, Smith SJ, Miller AJ, Davies JM, Newman IA (2006) Extracellular $\mathrm{Ca}^{2+}$ ameliorates $\mathrm{NaCl}$-induced $\mathrm{K}^{+}$loss from Arabidopsis root and leaf cells by controlling plasma membrane $\mathrm{K}^{+}$-permeable channels. Plant Physiol 141:1653-1665

Shabala S, Cuin TA, Pottosin I (2007a) Polyamines prevent NaClinduced $\mathrm{K}^{+}$efflux from pea mesophyll by blocking nonselective cation channels. FEBS Lett 581:1993-1999
Shabala S, Cuin TA, Prismall L, Nemchinov LG (2007b) Expression of animal CED-9 anti-apoptotic gene in tobacco modifies plasma membrane ion fluxes in response to salinity and oxidative stress. Planta 227:189-197

Shabala S, Shabala S, Cuin TA, Pang J, Percey W, Chen Z, Conn S, Eing C, Wegner LH (2010) Xylem ionic relations and salinity tolerance in barley. Plant J 61:839-853

Shabala S, Wu H, Bose J (2015) Salt stress sensing and early signalling events in plant roots: current knowledge and hypothesis. Plant Sci 241:109-119

Shabala L, Zhang J, Pottosin I, Bose J, Zhu M, Fuglsang AT, Velarde-Buendia A, Massart A, Hill CB, Roessner U, Bacic A, Wu H, Azzarello E, Pandolfi C, Zhou M, Poschenrieder C, Mancuso S, Shabala S (2016) Cell-type-specific $\mathrm{H}^{+}$-ATPase activity in root tissues enables $\mathrm{K}^{+}$retention and mediates acclimation of barley (Hordeum vulgare) to salinity stress. Plant Physiol 172:2445-2458

Sharbatkhari M, Shobbar ZS, Galeshi S, Nakhoda B (2016) Wheat stem reserves and salinity tolerance: molecular dissection of fructan biosynthesis and remobilization to grains. Planta 244: 191-202

Shen Y, Shen L, Shen Z, Jing W, Ge H, Zhao J, Zhang W (2015) The potassium transporter OsHAK21 functions in the maintenance of ion homeostasis and tolerance to salt stress in rice. Plant Cell Environ 38:2766-2779

Shin R, Schachtman DP (2004) Hydrogen peroxide mediates plant root cell response to nutrient deprivation. Proc Natl Acad Sci 101:8827-8832

Sklodowski K, Riedelsberger J, Raddatz N et al (2017) The receptor-like pseudokinase MRH1 interacts with the voltage-gated potassium channel AKT2. Sci Rep 7:1-12

Smethurst CF, Rix K, Garnett T, Auricht G, Bayart A, Lane P, Wilson SJ, Shabala S (2008) Multiple traits associated with salt tolerance in lucerne: revealing the underlying cellular mechanisms. Funct Plant Biol 35:640-650

Sohn JW (2013) Ion channels in the central regulation of energy and glucose homeostasis. Front Neurosci 7:1-10

Su H, Golldack D, Katsuhara M et al (2001) Expression and stressdependent induction of potassium channel transcripts in the common ice plant. Plant Physiol 125:604-614

Su H, Golldack D, Zhao C, Bohnert HJ (2002) The expression of HAK-type $\mathrm{K}^{+}$transporters is regulated in response to salinity stress in common ice plant. Plant Physiol 129:1482-1493

Sun J, Dai S, Wang R, Chen S, Li N, Zhou X, Lu C, Shen X, Zheng X, Hu Z, Zhang Z, Song J, Xu Y (2009) Calcium mediates root $\mathrm{K}^{+} / \mathrm{Na}^{+}$homeostasis in poplar species differing in salt tolerance. Tree Physiol 29:1175-1186

Sun J, Zhang X, Deng S, Zhang C, Wang M, Ding M, Zhao R, Shen X, Zhou X, Lu C, Chen S (2012) Extracellular ATP signaling is mediated by $\mathrm{H}_{2} \mathrm{O}_{2}$ and cytosolic $\mathrm{Ca}^{2+}$ in the salt response of Populus euphratica cells. PLoS One 7:e53136

Suzanne M, Steller H (2013) Shaping organisms with apoptosis. Cell Death Differ 20:669-675

Tran D, El-Maarouf-Bouteau H, Rossi M et al (2013) Posttranscriptional regulation of GORK channels by superoxide anion contributes to increases in outward-rectifying $\mathrm{K}^{+}$currents. New Phytol 198:1039-1048

Tsay Y-F, Ho CH, Chen HY, Lin SH (2011) Integration of nitrogen and potassium signaling. Annu Rev Plant Biol 62:207-226 
Van den Wijngaard PWJ, Bunney TD, Roobeek I et al (2001) Slow vacuolar channels from barley mesophyll cells are regulated by 14-3-3 proteins. FEBS Lett 488:100-104

van Ittersum MK, van Bussel LGJ, Wolf J, Grassini P, van Wart J, Guilpart N, Claessens L, de Groot H, Wiebe K, MasonD'Croz D, Yang H, Boogaard H, van Oort PAJ, van Loon MP, Saito K, Adimo O, Adjei-Nsiah S, Agali A, Bala A, Chikowo R, Kaizzi K, Kouressy M, Makoi JHJR, Ouattara K, Tesfaye K, Cassman KG (2016) Can sub-Saharan Africa feed itself? Proc Natl Acad Sci 113:14964-14969

Verslues PE, Batelli G, Grillo S, Agius F, Kim YS, Zhu J, Agarwal M, Katiyar-Agarwal S, Zhu JK (2007) Interaction of SOS2 with nucleoside diphosphate kinase 2 and catalases reveals a point of connection between salt stress and $\mathrm{H}_{2} \mathrm{O}_{2}$ signaling in Arabidopsis thaliana. Mol Cell Biol 27:7771-7780

Very AA, Nieves-Cordones M, Daly M et al (2014) Molecular biology of $\mathrm{K}^{+}$transport across the plant cell membrane: what do we learn from comparison between plant species? J Plant Physiol 171:748-769

Walker DJ, Leigh RA, Miller AJ (1996) Potassium homeostasis in vacuolate plant cells. Proc Natl Acad Sci 93:10510-10514

Wang Y, Wu W-H (2013) Potassium transport and signaling in higher plants. Annu Rev Plant Biol 64:451-476

Wang F, Deng S, Ding M, Sun J, Wang M, Zhu H, Han Y, Shen Z, Jing X, Zhang F, Hu Y, Shen X, Chen S (2013a) Overexpression of a poplar two-pore $\mathrm{K}^{+}$channel enhances salinity tolerance in tobacco cells. Plant Cell Tissue Organ Cult 112:19-31

Wang M, Zheng Q, Shen Q, Guo S (2013b) The critical role of potassium in plant stress response. Int J Mol Sci 14:7370-7390

Wang N, Qi H, Su G, Yang J, Zhou H, Xu Q, Huang Q, Yan G (2016a) Genotypic variations in ion homeostasis, photochemical efficiency and antioxidant capacity adjustment to salinity in cotton (Gossypium hirsutum L.). Soil Sci Plant Nutr 62:240-246

Wang Q, Dodd IC, Belimov AA, Jiang F (2016b) Rhizosphere bacteria containing 1-aminocyclopropane-1- carboxylate deaminase increase growth and photosynthesis of pea plants under salt stress by limiting $\mathrm{Na}+$ accumulation. Funct Plant Biol 43:161

Wolf O, Dieter Jeschke W (1987) Modeling of sodium and potassium flows via phloem and xylem in the shoot of salt-stressed barley. J Plant Physiol 128:371-386

Wu H (2016) Tissue specificity of cytosolic $\mathrm{K}^{+}$retention, $\mathrm{Na}^{+}$ extrusion, and vacuolar $\mathrm{Na}^{+}$sequestration traits in the context of differential salinity stress tolerance in barley and wheat. University of Tasmania, Australia, Hobart

Wu H, Shabala L, Barry K, Zhou M, Shabala S (2013) Ability of leaf mesophyll to retain potassium correlates with salinity tolerance in wheat and barley. Physiol Plant 149:515-527

Wu H, Shabala L, Zhou M, Shabala S (2014) Durum and bread wheat differ in their ability to retain potassium in leaf mesophyll: implications for salinity stress tolerance. Plant Cell Physiol 55:1749-1762
Wu H, Shabala L, Liu X et al (2015a) Linking salinity stress tolerance with tissue-specific $\mathrm{Na}^{+}$sequestration in wheat roots. Front Plant Sci 6:71

Wu H, Shabala L, Zhou M, Shabala S (2015b) Chloroplastgenerated ROS dominate $\mathrm{NaCl}$-induced $\mathrm{K}^{+}$efflux in wheat leaf mesophyll. Plant Signal Behav 10:e1013793

Wu H, Zhu M, Shabala L, Zhou M, Shabala S (2015c) K+ retention in leaf mesophyll, an overlooked component of salinity tolerance mechanism: a case study for barley. J Integr Plant Biol 57:171-185

Wu H, Shabala L, Azzarello E, Huang Y, Pandolfi C, Su N, Wu Q, Cai S, Bazihizina N, Wang L, Zhou M, Mancuso S, Chen Z, Shabala S (2018a) $\mathrm{Na}^{+}$extrusion from the cytosol and tissuespecific $\mathrm{Na}^{+}$sequestration in roots confer differential salt stress tolerance between durum and bread wheat. J Exp Bot 69:3987-4001. https://doi.org/10.1093/jxb/ery194

Wu H, Shabala L, Shabala S, Giraldo JP (2018b) Hydroxyl radical scavenging by cerium oxide nanoparticles improves Arabidopsis salinity tolerance by enhancing leaf mesophyll potassium retention. Environ Sci Nano 5:1567-1583

Xie Y, Han S, Li X, Amombo E, Fu J (2017) Amelioration of salt stress on bermudagrass by the fungus Aspergillus aculeatus. Mol Plant-Microbe Interact 30:245-254

$\mathrm{Xu} \mathrm{S}$, Hu B, He Z, Ma F, Feng J, Shen W, Yang J (2011) Enhancement of salinity tolerance during rice seed germination by presoaking with hemoglobin. Int J Mol Sci 12:2488-2501

Yanez A, Tapia G, Guerra F, del Pozo A (2017) Stem carbohydrate dynamics and expression of genes involved in fructan accumulation and remobilization during grain growth in wheat (Triticum aestivum L.) genotypes with contrasting tolerance to water stress. PLoS ONE 12:e0177667

Yang J, Zhang J (2006) Grain filling of cereals under soil drying. New Phytol 169:223-236

Yang T, Zhang S, Hu Y, Wu F, Hu Q, Chen G, Cai J, Wu T, Moran N, Yu L, Xu G (2014) The role of a potassium transporter OsHAK5 in potassium acquisition and transport from roots to shoots in rice at low potassium supply levels. Plant Physiol 166:945-959

Yu Y, Wang A, Li X et al (2018) Melatonin-stimulated triacylglycerol breakdown and energy turnover under salinity stress contributes to the maintenance of plasma membrane $\mathrm{H}^{+}-$ ATPase activity and $\mathrm{K}^{+} / \mathrm{Na}^{+}$homeostasis in sweet potato. Front Plant Sci 9:1-15

Zepeda-Jazo I, Shabala S, Chen Z, Pottosin II (2008) $\mathrm{Na}^{+}$$\mathrm{K}^{+}$transport in roots under salt stress. Plant Signal Behav 3: 401-403

Zhao J, Li P, Motes CM, Park S, Hirschi KD (2015) CHX14 is a plasma membrane K-efflux transporter that regulates $\mathrm{K}^{+}$ redistribution in Arabidopsis thaliana. Plant Cell Environ 38:2223-2238

Zorb C, Senbayram M, Peiter E (2014) Potassium in agriculturestatus and perspectives. J Plant Physiol 171:656-669

Zwiewka M, Nodzyński T, Robert S, Vanneste S, Friml J (2015) Osmotic stress modulates the balance between exocytosis and clathrin-mediated endocytosis in Arabidopsis thaliana. Mol Plant 8:1175-1187 